\title{
MEXICO AND THE EUROPEAN UNION: A STRATEGIC PARTNERSHIP IN TIMES OF GLOBALIZATION
}

\author{
José Guillermo ORDORICA ROBLES \\ National University of Political Studies and Public Administration, PhD \\ Candidate at the Multidisciplinary Doctoral School of SNSPA \\ Bucharest/Romania
}

\begin{abstract}
This paper reviews the way in which Mexico and the European Union (EU) established a strategic partnership. In a globalized world and following the Washington Consensus both signed, in March 2000, a Free Trade Agreement (TLCUEM) which entered into force in October 2000. The good results of the bilateral exchanges plus important events in the world encouraged them, in 2016, to renovate the legal framework of the original Agreement. At the end of 2017, the negotiators finished the revised chapters of political dialogue and cooperation and on April 2018 they reached an agreement in principle on a modernized trade pillar of the EU-Mexico Global Agreement (GA). By 2020, negotiations were over. It is expected that after the trade pillar's legal scrutiny and translation, it will become part of the three-pronged GA that will also contain revamped political dialogue and cooperation pillars. After 20 years of its subscription, results are promising. Representing $26 \%$ of world GDP, the EU is a key partner for Mexico, and Mexico, with 12 free trade agreements signed with 46 countries, for the EU. The cooperation has encouraged exchanges in subjects of common interest, such as the fight against pandemic and gender equality.
\end{abstract}

\section{Keywords}

Cooperation; free trade; gender; globalization; pandemic; partnership. 


\section{CURRENT DIAGNOSIS}

After the Fall of the Berlin Wall, a series of important events occurred that changed the shape of the world. It was not just a matter of geography and borders, but also reflected a major ideological turn, which affected the economy and opened the door to new technological developments, which would precipitate a revolution in communications. As a major international event, the collapse of communism in Eastern Europe had widespread consequences in all fields of life. Since that time, all countries in the world needed to make major adjustments to their approach to international relations, considering that the new era brought with it a drastic change in the paradigms of peace and war, cooperation and conflict. Also, for the first time in recent history, there were significant feelings of optimism, because the dissolution of real socialism was thought to foretell the arrival of a time of harmony, peace, and, finally, the achievement of new levels of development across the world, a goal that the United Nations (UN) had never achieved before, despite the efforts it deployed in favour of a fairer economic and social system.

The so-called "Washington Consensus," reached after the debt crisis in Latin America in the mid-1980's, and the values it put forward for progress, were immediately embraced by most nations, in particular the values of democracy, free trade, Human and gender rights, and the preservation of natural resources to avoid ecocide. These values were also embraced in the multilateral agenda, especially at the UN, which gave them priority over other traditional topics that had been calling the attention of the international community in the previous decades. A major experiment was then already in progress: in the Americas, Mexico, the US, and Canada signed the North American Free Trade Agreement (NAFTA) in 1994, while in Europe, ambitious steps were taken to consolidate the European Union as a common space for its members to cooperate on matters of the economy, security and foreign policy. ${ }^{1}$

1 The European Union contains 27 states. Its origins go back to the Schuman Declaration (1950) and the Europe Declaration (1951). Later, in spite of the need of advancing 
Yes, the optimistic view of this period was nurtured as a result of the fatigue following the consequences of the East-West conflict and the possibility of a major nuclear war. This fatigue brought about the idea, later proven wrong, that major threats of conflict would be a thing of the past, since at that moment the emerging conditions seemed to show ways for progress through diplomacy and the respect for common values. The 9/11 terrorist attacks in the United States rocked this view, showing that new threats to the liberal order had been brewing as a consequence of unresolved conflicts in different parts of the world, in this particular case as a result of the persistent conflict in the Middle East. For those who were relieved at the thought that nuclear weapons no longer posed a threat and that the arms race was over, terrorism brought a new concern to light, including the possibility that terrorist organizations could manage to acquire weapons of mass destruction through channels left open by failed states and nefarious actors interested in profiting from the arms trade.

However, the optimistic view was not entirely lost and prevailed over pessimism about the post-Communist order. The positive economic results of free trade were expected to be shared by all countries, with the hope of diminishing the gap between the rich and the poor and improving Human Rights all over the world. At the same time, the widespread adoption of Western-style democracy as the prevailing political system, as the only one able to provide safety and opportunities to the people, also gave some positive initial results in terms of political empowerment and social stability. Unfortunately, the promise of a new era did not last for long. According to David Malpass, President of the World Bank Group, more than 1\% of the world's population could fall in extreme poverty because of Covid-19 pandemic and world recession. Also, the combination of the pandemic with the pressures coming

integration processes the Treaty of Rome (1958) established the European Economic Community (EEC) and the European Atomic Energy Community (EAEC). After the fall of The Berlin Wall, through the Maastricht Treaty (1992), the European Union was founded. As a result, its members adopted the same currency (Euro) and a common security and foreign policy. Since then, the process of integration has been completed with other initiatives, in particular the adoption of the Schengen space, which establishes the borders of the EU. 
from conflicts and climate change, will make it impossible to achieve the goal of putting an end to poverty by the year 2030 when, on the contrary, it could reach an additional $7 \%$ of the world's population (World Bank 2020).

Globalization soon began to show its real face, as a system that resulted in the concentration of wealth in only a few hands, while the majority of people around the world had no agency and no access to the wealth being generated. The global Multidimensional Poverty Index (MPI) produced by the United Nations Development Program (UNDP) and the Oxford Poverty and Human Development Initiative, shows that worldwide, across 109 countries and 5.9 billion people, 1.3 billion people are multidimensionally poor; about half (644 million) are children under age 18; nearly 85\% live in Sub-Saharan Africa (556 million) or South Asia (532 million) and more than $67 \%$ live in middle-income countries. The same MPI shows that Covid-19 pandemic has eroded development progress around the world, and we are still grappling to understand its full impacts. While complete data on Covid-19's impact on the MPI are not yet available, the pandemic has exposed cracks in social protections systems, education, and workers' vulnerability around the world. These cracks, the report shows, are deepest in countries with higher levels of multidimensional poverty (UNDP, 2021). The consequences of this were clear: weak democracies, unstable national institutions, and the failure of the rule of law in many countries, all of which resulted in social disruption and a fundamental questioning of the ability and merits of globalization to redress the problems of the former era, in particular those regarding development.

A good example of this social disruption was offered by Pope Francis in a video message that he sent to the participants in the IV World Meeting of Popular Movements, inviting them to dream and work together through solidarity and subsidiarity, for building a better society and a better outcome for the Covid-19 pandemic. In this message, Francis made a strong call to reverse conditions that create inequalities, hunger and widespread poverty in the world (Vatican News 2021).

The current global scenario is far from the original expectations nurtured following the collapse of Communism. Faced with this reality, and with the growing economic, political, and military influence of powers like China and 
Russia, the international community is today grappling with the weaknesses of globalization and trying to update the major agreements that were made following the Washington Consensus. In the case of Mexico, the US and Canada, they revised NAFTA and negotiated a new trade agreement, known as T-MEC, which provides better tools for improving trade and exchanges within North America. At the same time, after Brexit pointed out the weaknesses of European integration, the European Union is wrestling with a new reality in which member states are not always satisfied with the trends of integration, while others think of this integration as the only option for survival, especially in Eastern and Southern European countries.

This diagnosis, while cursory, is more than enough to present the major challenges of today. Unfortunately, the world was hit with an unexpected crisis: the Covid-19 pandemic placed itself at the top of the global agenda, displacing and delaying all other major concerns in international affairs. As of today, uncertainty is the reality for most nations. Yes, the pandemic brought death, tragedy, fear, and instability. The figures are brutal, and show how vulnerable humankind is and how far away the international community is from having the proper tools to deal with this kind of global emergency. Following Pope Francis' reflections, the Covid-19 pandemic has increased by 20 million the number of people who have been dragged into extreme levels of food insecurity this year. He considers the need for a universal wage and the reduction of the working day, and also appeals to financial groups and credit institutions to wave debts in order to allow poor countries to guarantee the basic needs of their people (Vatican News 2021).

However, in the dark, there is always some light. As a result of this major sanitary crisis, the international community showed its ability to work together, developing vaccines in record time against the virus and calling the attention of the richest countries on earth to the need to provide vaccines and other health resources to less fortunate countries. It is expected that this moment will show the rise of a renewed concept of solidarity among nations and peoples as a common family, co-responsible for responding to the crisis, and by extension to other issues that affect humanity. 
In the difficult conditions created by globalization, and aggravated by the pandemic, many countries have begun to rethink and reshape the way in which they engage with other nations, blocs, and the wider world. This is the case of Mexico and the European Union. Despite new realities, both entities identified in the global arena a window of opportunity and, in 2016, decided to update the "Global Agreement," which frames their institutional relations and exchanges. The Global Agreement was signed in 1997 with an Interim Trade Agreement that was later replaced by the Free Trade Agreement between Mexico and the EU (TLCUEM). Signed in March 2000, the Global Agreement and TLCUEM entered into force in October 2000.

\section{MEXICO AND EUROPE}

Talking about Mexico and Europe is to make reference to a long history of friendship and cooperation, in different fields. It is also to make reference to solidarity and possibilities of diversification and complementation that their economies and societies offer to each other. From the Mexican perspective, it is a relation with strong foundations that offers horizons for widening contacts and exchanges. Mexico finds in Europe the convergence of different agendas, some that rule bilateral relations, others related to multilateral and bi-regional diplomacy. At the same time, Europe finds in Mexico a trustable partner and a gateway to the North American market and to the Latin American and Caribbean regions. Mexico and Europe share values, among them the rule of law, transparency, gender and Human rights, the fight against climate change, democracy and free trade, following the rules of the World Trade Organization (WTO). It is also important to underline the fact that in times of globalization, the partnership between Mexico and the European Union has offered both with better tools for positioning themselves as co-responsible actors regarding subjects of common interest.

In 2017, Mexico and the European Union celebrated the twentieth anniversary of their Global Agreement. As a result of this Agreement, they have reinforced their condition as strategic partners. With a total population of over 500 million 
people, $26 \%$ of world GDP, and some of the most powerful economies in the world, the European Union represents a significant strategic partner for Mexico (De Icaza 2018, 19-31). Mexico represents something similar for Europe, thanks to the country's condition as one of the most globalized and open in the world for more than two decades. Since 1994, Mexico has signed twelve free trade agreements, with 46 countries. Thirty-three agreements for the reciprocal promotion and protection of investments (15 of them with 16 European Union countries) and nine agreements of limited scope. At the same time, Mexico participates in several regional and multilateral fora, such as the World Trade Organization (WTO), the Asia-Pacific Economic Cooperation Forum (APEC), the Organization for Cooperation and Economic Development (OCED), and the Pacific Alliance (with Chile, Colombia and Peru).

The diversification process is founded on the search for new partners, the deepening of existing coordination and consultation mechanisms, and the commitment to cooperation for development. According to the European Commission, in the last decade, total EU-Mexico trade in goods has almost tripled, reaching $€ 61.8$ billion in 2019, with the EU running a trade in goods surplus with Mexico of $€ 13.3$ billion. That same year, Mexico was the $11^{\text {th }}$ largest trading partner for the EU-27 and its biggest trading partner in Latin America ahead of Brazil ( $€ 59.0$ billion as per February 2020 data). Again in 2019, the EU27 was Mexico's third-largest trading partner, accounting for a share of $7.8 \%$ of Mexican trade after the US (62.4\%) and China (10.1\%). Unlike the EU's agrifood-dominated imports from other Latin American countries, EU imports from Mexico - just like EU exports to Mexico - are mainly in the form of industrial goods (94.7\% and 96\% respectively). In 2019, EU imports of agricultural products and fisheries from Mexico accounted for only $4.9 \%$ and $0.5 \%$ respectively, and EU exports of those goods to Mexico for merely $3.9 \%$ and $0.1 \%$ respectively. Following the same source, in 2019 Mexico was the EU's 23rd largest import market for agri-food, accounting for $€ 1.4$ billion or $0.8 \%$ of total extra-EU trade, and the EU's $28^{\text {th }}$ largest export market for agri-food, representing $€ 1.1$ billion or $1 \%$ of total extra-EU trade. In 2018, overall EUMexico trade in services amounted to $€ 13.2$ billion. EU exports of services to Mexico accounted for $€ 8.2$ billion and consisted mainly of business ( $€ 2.8$ billion), 
transport (€1.8 billion), travel (€0.7 billion) and ICT services (€0.6 billion). EU imports of services from Mexico represented $€ 5$ billion and were dominated by business ( $€ 1.5$ billion), transport ( $€ 1.0$ billion) and travel ( $€ 0.8$ billion) (European Parliament. Modernisation of the trade pillar of the EU - Mexico Global Agreement 2020).

The relation between Mexico and the European Union has proved to be strategic for both. Since the year 2000, the relation has been institutionalized, and the Global Agreement, the first of its kind in the European Union with a Latin American country, offers certainty to relations between the two entities. The metrics show that the European Union is the third-largest trade partner of Mexico, following the United States and China. The trade exchanges between Mexico and the European Union are over 62 billion Dollars, out of which the EU exports to Mexico almost 42 billion (67\% of total trade). From 1999 to 2021, the amount of the direct European investment in Mexico was over 193 billion Dollars, the equivalent to $31.34 \%$ of the total Foreign Direct Investment received. In Mexico there are 19,313 companies with investments from the European Union (La relación comercial entre México y Europa 2021).

The promising results of the bilateral exchanges between Mexico and the European Union, plus important economic and political changes in the two regions and the world over, required a more robust agreement between Mexico and the EU. In 2009, the Treaty of Lisbon entered into force, and the capacities of the European Union widened regarding its member states and towards external partners. At the same time, the number of members of the European Union has grown to almost double what it was in 1997 (when they were fifteen) to today's twenty-seven, after the United Kingdom signaled in 2016 that it would withdraw and finally achieved Brexit in 2020. In consequence, a process of renovation of the legal framework of the original agreement between Mexico and the EU began in 2016.

The original TLCUEM, established in 1997, contained three chapters: political concertation, economic association, and cooperation. In the political field, the most important change for both entities was their decision to become strategic partners, which was later consolidated through the Strategic Partnership in 2009 and the Joint Executive Plan (2010), which proposed actions and common goals 
in bilateral, regional, and multilateral areas of common concern. At the same time, the creation in 2011 of the Mexican Agency for Cooperation for International Development (AMEXCID) updated Mexico's platform for dealing with this important component of the previous agreement, to put it in accordance with the Millennium Development Goals (MDG's) outlined by the United Nations. AMEXCID is a satellite entity of the Mexican Ministry of Foreign Affairs that has the specific mandate regarding international cooperation for development.

The negotiation process was agreed upon in 2013, and three years later, the European Council approved the beginning of negotiations. After several rounds, on 30 November 2017, the negotiators successfully finished the revised chapters of political dialogue and cooperation. On 21 April 2018, the EU and Mexico reached an agreement in principle on a modernized trade pillar of the EUMexico Global Agreement. Two years later, negotiations were formally concluded. The trade pillar of the Global Agreement was the first trade liberalization instrument that the EU concluded with a Latin American country. It has contributed to a significant increase in EU-Mexico trade in services and industrial goods. After the trade pillar's legal scrutiny and translation, it will become part of the three-pronged Global Agreement, that will also contain revamped political dialogue and cooperation pillars.

The progress achieved by both parties is important, but steps are still necessary to ensure that the new agreement is approved by all member states and Mexico in their respective legislatures. It is expected that the renewed Global Agreement will consolidate the partnership between the European Union, its member states, and Mexico. The modernization process of the Global Agreement will also help to expand the trade and investment bonds, intensify political dialogue, and widen cooperation between the partners, taking into account the ability both parties have to influence global governance. Before the agreement is passed to the Council of the European Union for its final approval, the text must go through a legal review and be translated into all the official languages of the European Union, considering that the original text was negotiated in English. Once approved by the Council, Mexico and the EU will sign the agreement and the text will be submitted for consideration to the Mexican Senate and the 
European Parliament. After that, it will go to the national parliaments of each Union member state, and in some cases the sub-national legislatures, for its ratification. (Del Rio and Saavedra Cinta 2018, 35-48).

\section{THE CHALLENGES AHEAD}

Putting aside the process of the final approval of the Global Agreement, which is ongoing, a prospective analysis shows the richness and amplitude of possibilities that this instrument offers Mexico and the EU for redressing their relations and persistent problems in the world in the third decade of the $21^{\text {st }}$ century. Great challenges lie ahead. Among them are the issues presented by migration and the management of borders; Human and gender rights at a moment in which feminisms across the globe are being redefined; the issues of crisis management raised by the Covid-19 pandemic and other health crises; the need to adopt policies able to ensure a more equitable distribution of wealth and prosperity, in particular the reduction of poverty; and the strengthening of democratic systems of government by ensuring fairness, participation and social justice. To these we must add the need to address topics such as the rule of law, transparency and environmental sustainability. The shared goals of Mexico and the European Union should have a meaningful impact on the lives of their populations and contribute to improving world governance, including the reform of the multilateral system in such a way that it can be representative of today's world and its diverse needs.

It is important to acknowledge that the process of renewing the Global Agreement sends a strong message to the world about the importance of resisting protectionism and isolationism. It is also a strong signal of both parties' will to reinforce their strategic partnership, which, moreover, is useful for strengthening bonds on the bilateral level between Mexico and the member states of the European Union. This trend has set a standard for cooperation, exchanges, and reciprocal visits of businesspeople and dignitaries, which has proved to be helpful for adapting their diplomacies to changing conditions and has helped to foster their convergence on different topics on the multilateral 
level. At a time in which multilateralism was seriously questioned by the administration of former United States president Donald Trump, the evolution of the Mexico-EU Global Agreement is a good example of a functioning multilateral instrument committed to development and able to offer support for the strengthening of institutions under a non-selective framework. The MexicoEU Global Agreement is unique in Latin America and the Caribbean, a region which has been approached by Europe in the past with many expectations, but which has experienced changes that have prevented Brussels from continuing to approach the region as a whole.

For the moment, following the difficulties of the CELAC-EU dialogue to deal with the growing diversity and divergences of its Latin American and Caribbean member states, the European Union has taken distance from the region, and now is focusing on cooperation programs, not on the wide range of topics previously considered on the agenda. An example of the complex but constructive relationship of Europe with Latin America is the role of Norway, not an EU member, as a mediator in the dialogue between the regime of Venezuela's Nicolas Maduro and the opposition parties, currently taking place in Mexico City. In this instance, Mexico again showed itself to be, as it has always been, an ally of dialogue for peace and a state committed to the rule of law.

At the bilateral level, Mexico and its European partners work together for the promotion of laws and policies with the potential to enact cultural and social changes. This happens internationally through the encouragement of progressive standards to strengthen domestic strategies. The added value of the Global Agreement is to be an instrument designed to last and ensure a stable future of relations between Mexico and the EU member states. So far, the Agreement has proved able to adapt to the changing conditions that affect its parties, even at a time of a major global crisis, as seen during the Covid-19 pandemic.

One particular challenge is the growing Euro-skepticism affecting both EU member countries and views about the bloc from outside it. After Brexit, and, more recently, the end of Angela Merkel's tenure as German chancellor (since Merkel was one great promotor of Europeanism), the situation is very complex. 
In Western Europe, there are doubts about the ability of the EU to embrace all European countries, in particular those from the East and the South, which are in general less developed and see the European Union as a catalyst for progress, economic stability and development. At the same time, since those countries lie on the boundaries of Europe, they are often seen in Brussels as a crucial first line against external threats to the cultural identity and political stability of the bloc. For geographically distant observers of these dynamics, Euro-skepticism seems to be more a matter of concern for Europe, rather than for other actors. In the current reality, the EU is still seen as a strong and reliable partner to other entities in the world, because it has proved that it has the ability to renew and reinvent itself in the face of changes. None of what happens in Europe is alien to Mexico, or vice-versa. The number of exchanges and the strength of cooperation between the two entities continues to be robust, despite intra-European political fluctuations. In this context, the Global Agreement is a useful tool that empowers Mexico vis-à-vis the EU as a whole and with its member states individually. Going forward, both parties need to continue working with renewed vigor for their diplomacies. They also need to adopt a strong political dialogue, able to enrich the common agenda and identify their points of contact in the multilateral arena. The work that both parties are doing to update the Global Agreement confirms the belief on both sides that this is not the moment to take distance from one another, but on the contrary to reinforce bonds at a time of great challenge.

\section{GENDER RIGHTS, A SUBJECT OF COMMON INTEREST}

No analysis of Mexico-EU relations would be complete without considering the ways in which both have worked to address a significant issue of common interest: gender equality. Mexico is the first Latin American country to adopt a feminist foreign policy (FFP), which considers the perspective of gender in a transversal way, and is focused on Human Rights. Up until now, four countries in the world have had a similar policy, namely France, Norway, Switzerland and Canada. By joining their ranks, Mexico seeks, with FFP, to reduce and one 
day eliminate structural differences and gender inequalities, as a way to build a more fair and prosperous society. This policy makes visible women's contributions to foreign policy and actions on a global scale, while maintaining coherence with the trends of the wider world and within the Mexican Ministry of Foreign Affairs (Gobierno de México 2020).

Naturally in solidarity with the causes of humankind, FFP is supported by an effective diplomatic practice that is backed by the Constitution of Mexico and the international agreements signed with other countries and blocs, including with the EU. As an example of this commitment, Mexico and France partnered on the bilateral level to create the "Gender Equality Forum" (GEF), which met in Mexico City in March, 2021, and in Paris in June, 2021. The results of these meetings, which were convoked by UN Women and co-sponsored by Mexico and France, in association with civil society groups and youth organizations, sent a strong message of cooperation to the European Union and its member countries about the power of activism for the rights of women, feminist solidarity and youth leadership for making a transformative change. Of particular importance was the fact that these meetings occurred even during the sanitary crisis and hence, Mexico and France considered that gender equality, the promotion of Human Rights and the elimination of all forms of discrimination and violence against women and girls, had to be vital components for the building of a more egalitarian, inclusive and sustainable world.

Through the Global Agreement, Mexico and the EU would have the chance to continue dialoguing about topics related to gender equality and the challenges faced by both of them in this important field. Gender equality is precisely one of the most prominent shared values of both entities. It has to do not just with Human Rights, but also with democracy and global social justice. At the universal level, the topic is also one of the pillars that gives cohesion to the United Nations. It is expected that the conversation between Mexico and the EU will be mutually enriching, especially because the gender equality strategy of the European Union, even though it has been signed by its member states, is not a responsibility of the Union. The EU member states in fact diverge widely in its implementation. 
Gender equality offers a strong example of how Mexico can also contribute significantly, through the exchange of good practices, to the development of measures and policies adopted by the EU and its member states to improve the lives of women and girls. By law in Mexico, political parties must ensure that fifty per cent of all candidates for elective office are women. A natural consequence of this is that, for the first time in history, the number of Congresswomen (250) is the same as that of Congressmen (250) in the Chamber of Deputies. The strength of the feminist movement in Mexico is a model for feminist movements across the world, and in Europe. The protection of women and girls from violence, parity between men and women and their continued empowerment in all fields of life are top priorities for the Mexican government, and offer elements for strengthening the dialogue and sharing experience with the European Union.

\section{PROSPECTIVE}

At present, the EU is facing a complex moment. Euro-skepticism, Brexit and the consequences of the Covid-19 pandemic pose serious challenges to Europeanism and call the attention of the EU members about the possibility of setting new priorities, able to redress the goals of the community and its role with other international actors. The evolution of events is still strongly attached to the outcome of the pandemic, which for the moment is at the top of everyone's priority list. While some European States have achieved the goal of having at least $70 \%$ of their population vaccinated, others, in the East and South of the continent, are facing serious trouble because their national rate is still poor and economic and social activities are restricted. However, the international and extra-continental bonds of the EU are still active, as is evident in the process of signing the Global Agreement with Mexico.

On the other hand, and in different conditions, when Mexico has achieved a promising result for the control of the pandemic, the government is deploying a strong effort to consolidate its foreign policy strategy for the diversification of contacts all around the world, including the European Union as such and its 
member states on the bilateral level. With the strong support offered by its soft power (Nye 2005), Mexico is building bridges and interacting in globalization, with the mindset of achieving cooperation for development goals, to better distribute wealth and to tackle poverty.

Not exempt from challenges, Mexico and the EU share the potential of continuing to offer the world a good example of how friends and partners are able to strengthen bonds of cooperation. The new Global Agreement is certainly the confirmation of the political will of the parties to benefit from the experience achieved in years past and also of their efforts to update an instrument that has proved to be very useful, but that needed to be revised faced with emerging challenges.

Much can be said about the importance of the bonds between Mexico and the EU. The lessons learned and experience gained by both offer a very strong platform for the continued improvement of contacts. Looking ahead, and with open minds, the two parties are called to be in partnership under the principles of friendship and corresponsibility. It cannot be any other way. The size of the challenges that the world faces and the emergency posed by the Covid-19 pandemic have opened gates of opportunity for cooperation and urge the strengthening of the tools that Mexico and the EU have for addressing their shared agenda.

Based on common values and shared opinions about how to deal with world affairs through multilateral channels and with bold diplomacies committed with free trade, democracy, the rule of law, Human Rights and the common struggle against climate change, the Global Agreement offers Mexico and the EU a bright future as trustable partners. The time is right for advancing a strategic relation that has proved to be crucial for dealing with a complex, challenging and promising phase of globalization.

\section{REFERENCES}

- De Icaza, Carlos. 2018. "México y Europa: una historia de amistad, solidaridad, y cooperación" [Mexico and Europe: a history of friendship, 
solidarity and cooperation].Ruano, Lorena, et. al. Europa y su relación con México. Revista Mexicana de Política Exterior 112. Instituto Matías Romero, Secretaría de Relaciones Exteriores, México. 19-31.

- Del Rio, Francisco and Saavedra Cinta, Raúl. 2018. "Modernización de los capítulos de diálogo y cooperación del Acuerdo Global México-Unión Europea" [Modernization of the chapters regarding the dialogue and the cooperation of the Mexico - European Union Global Agreement]. Ruano, Lorena, et. al. Europa y su relación con México. Revista Mexicana de Política Exterior 112. 35-48.

- European Parliament. 2020. Modernisation of the trade pillar of the EU - Mexico Global Agreement. https://bit.ly/3pkq4t9.

- Gobierno de México. 2020. México anuncia la adopción de su Política Exterior Feminista [Mexico announces the adoption of its Feminist Foreign Policy]. https://www.gob.mx/sre/prensa/mexico-anuncia-la-adopcion-de-supolitica-exterior-feminista?state= published.

- SafeLink. 2021. La relación comercial entre México y Europa [The commercial relationship between Mexico and Europe]. https://www.safelinkmexico.com/la-relacion-comercial-entre-mexico-yeuropa/.

- Nye, Joseph S. Jr. 2005. Soft Power: The Means to Success in World Politics. New York: Public Affairs.

- UNDP, Press Release. 2021. Poverty index reveals stark inequalities among ethnic

groups. http://hdr.undp.org/sites/default/files/2021_mpi_press_release_en.pdf.

- Vatican News. 2021. Pope to Popular Movements: You create hope and forge dignity. https://www.vaticannews.va/en/pope/news/2021-10/popepopular-movements-poets-solidarity-subsidiarity-hope.html.

- World Bank. 2020. Covid-19: to add as many as 150 million extreme poor by 2021. https://www.worldbank.org/en/news/pressrelease/2020/10/07/covid-19-to-add-as-many-as-150-million-extremepoor-by-2021. 